\title{
Triflic Anhydride Promoted Synthesis of Primary Amides and their Conversion into Nitriles
}

\author{
Anil Rana \\ Varun Kumar \\ Lata Tiwari \\ Anamika Thakur \\ Chhuttan Lal Meena \\ Dinesh Mahajan*
}

dinesh.mahajan@thsti.res.in

chemidinesh@gmail.com
Drug Discovery Research Center, Translational Health Science and Technology Institute Faridabad, 121001, India

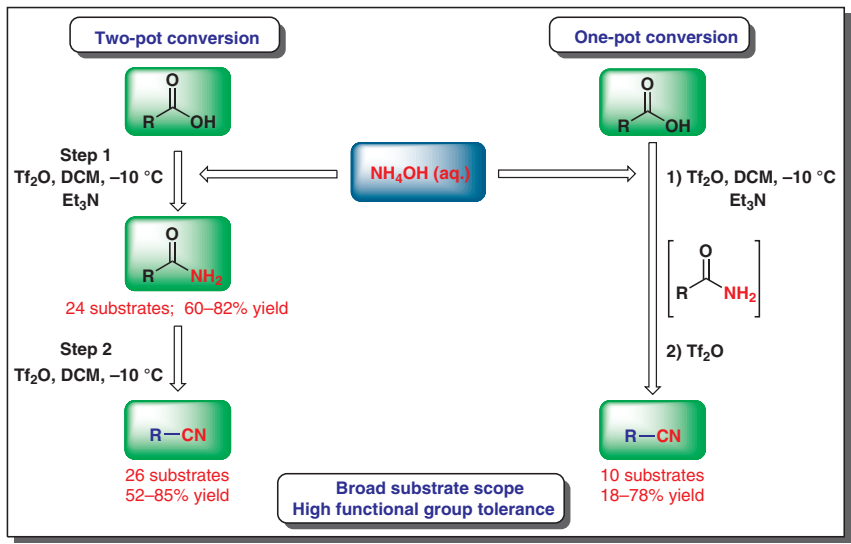

are often employed as precursors for heterocycles such as thiophenes and fused thiophenes, furans, pyrroles, pyridines, quinolones, pyrans, tetrazoles, and isoxazoles. ${ }^{5}$

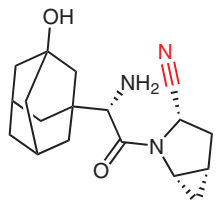

Saxagliptin

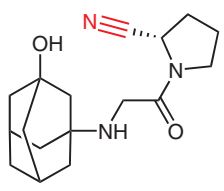

Vildagliptin<smiles>CC(C)(C#N)c1cc(Cn2cncn2)cc(C(C)(C)C#N)c1</smiles>

Anastrazole

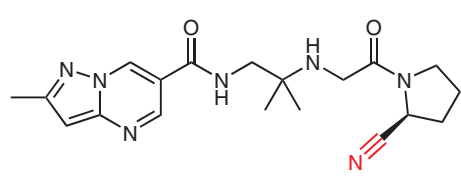

Analgliptin hydroxide

The nitrile functional group constitutes an important structural motif that is present in many organic molecules be they pharmaceutical agents, ${ }^{1}$ natural products, ${ }^{2 a}$ agrochemicals, ${ }^{2 b}$ fine chemicals or dyes. ${ }^{2 c}$ Around 120 natural products containing the nitrile functionality have been isolated from terrestrial and marine sources. ${ }^{2}$ The presence of a nitrile group can provide chemical and metabolic stability and enhanced solubility and biocompatibility compared with primary amides or carboxylic acids. ${ }^{3}$

There are 30 approved drugs and 20 more in clinical development that contain a nitrile as a key functional group; for example anastrazole, cimetidine, saxagliptin and other gliptin analogues (Figure 1). ${ }^{1}$ Apart from this, the nitrile group serves as a valuable precursor in organic synthesis as it can be transformed into a variety of functional groups such as acids, amides, amines, aldehydes, esters, imidates and amidines. ${ }^{4}$ Given their versatility and reactivity, nitriles
Figure 1 Examples of pharmaceuticals containing a nitrile moiety

Synthetic approaches to nitriles are primarily focused around dehydration of amides. While there are methods that do not include dehydration of amides, such as the Rosenmund-von Braun protocol and a one-pot conversion of alcohols and aldehydes into nitriles, ${ }^{6}$ dehydration of amides is still the most common approach for synthesis of nitriles. $^{7}$ Most of the DPP4 inhibitor drugs such as vildagliptin, sexagliptin and anagliptin, contain nitrile groups that are synthesized from the corresponding amides. ${ }^{7}$ Thus, a simple conversion of acids into primary amides followed by a dehydration to nitriles using a single reagent, preferably in one-pot, would be of significant value compared to existing methods. Along these lines, there is a report of the use of tosyl amide and $\mathrm{PCl}_{5}$ at $200{ }^{\circ} \mathrm{C}$ for the direct conversion of carboxylic acids into nitriles. ${ }^{8}$ Subse- 
quently, direct conversion of acids into nitriles was demonstrated using either silica as catalyst ${ }^{9}$ at $500{ }^{\circ} \mathrm{C}$ or ethyl polyphosphate ${ }^{10}$ at $80^{\circ} \mathrm{C}$, with ammonia gas acting as the source of nitrogen. Other reports for the direct synthesis of nitriles include reaction of carboxylic acids with 2,4-dinitrobenzenesulfonamide/oxalyl chloride, ${ }^{11}$ bis(2-methoxyethyl)aminosulfur trioxide, sodium azide/triphenyl phosphine, ${ }^{12}$ and diphosphorous tetraiodide/ammonium carbonate. ${ }^{13}$ Recently Miyagi et al. reported the one-pot conversion of carboxylic acids into nitriles. This method involves formation of the ester and its transformation into the corresponding aldehyde using SDBBA-H. The aldehyde thus formed is converted into an imine, which is eventually transformed into a nitrile by using iodine as catalyst. ${ }^{14}$ However, all these reported methods require harsh conditions such as high temperature, strongly acidic reagents, metal azides, rigorously anhydrous conditions, complex addition sequences and expensive catalysts or reagents, which limit their synthetic applicability. Therefore, it is highly desirable to develop a simple, mild, efficient and economical method for conversion of acids into nitriles.

To support our internal drug discovery efforts, we were keen to develop a mild and robust method for conversion of acids into primary amides and primary amides into nitriles to generate structural diversity for lead generation. The focus was to develop a practically simple yet selective transformation at a late stage of the synthesis of lead molecules. In recent years, triflic anhydride mediated amide bond activation has attracted considerable attention. ${ }^{15}$ Chemoselective activation of secondary and tertiary amides using trifluoromethanesulfonic anhydride $\left(\mathrm{Tf}_{2} \mathrm{O}\right)$ leads to iminium ion intermediates that can be transformed into a variety of functional groups including aldehydes, ketones and ester imidates. ${ }^{15}$ However, use of triflic anhydride for activation of acids for the synthesis of primary amides had not been reported and hence we envisaged the formation of primary amides using $\mathrm{Tf}_{2} \mathrm{O}$ and ammonia and their subsequent conversion into nitriles. With this aim, we initially focused our efforts on synthesis of primary amides from the corresponding carboxylic acids using $\mathrm{Tf}_{2} \mathrm{O}$. As a model reaction, benzoic acid was treated with $\mathrm{Tf}_{2} \mathrm{O}$ followed by addition of triethylamine and ammonium chloride at $0{ }^{\circ} \mathrm{C}$. This model reaction afforded only traces of desired amide $\mathbf{1 a}$ along with unchanged carboxylic acid (Table 1, entry 1 ).

It was decided to screen different reagents as a source of ammonia for the replacement of $\mathrm{NH}_{4} \mathrm{Cl}$ to optimize the yield of 1a. Three different ammonium salts, namely, ammonium carbonate, ammonium thiocyanate, and ammonium bicarbonate, were screened as a source for ammonia (Table 1, entries 2-4) but, to our disappointment, none of these provided yields of more than $35 \%$ of the desired amide. In all the cases, starting material 1 was recovered as the major component of the reaction. Somewhat surprisingly, a reaction attempted with aqueous ammonium hydroxide ( $28 \%$ water solution) led to formation of the desired product
Table 1 Optimization Study for Conversion of Acid (1) into Amide $(1 \mathrm{a})^{\mathrm{a}}$

\begin{tabular}{|c|c|c|c|c|}
\hline \multirow[b]{2}{*}{ Entry } & \multirow[b]{2}{*}{ Solvent } & \multicolumn{2}{|c|}{$\underset{\text { ammonia source }}{\stackrel{\mathrm{Tf}_{2} \mathrm{O} \text {, base }}{\longrightarrow}}$} & \\
\hline & & Base & Ammonia source & Yield of $\mathbf{1 a}(\%)$ \\
\hline 1 & $\mathrm{CH}_{2} \mathrm{Cl}_{2}$ & $\mathrm{Et}_{3} \mathrm{~N}$ & $\mathrm{NH}_{4} \mathrm{Cl}$ & traces \\
\hline 2 & $\mathrm{CH}_{2} \mathrm{Cl}_{2}$ & $\mathrm{Et}_{3} \mathrm{~N}$ & $\mathrm{NH}_{4} \mathrm{HCO}_{3}$ & 30 \\
\hline 3 & $\mathrm{CH}_{2} \mathrm{Cl}_{2}$ & $\mathrm{Et}_{3} \mathrm{~N}$ & $\left(\mathrm{NH}_{4}\right)_{2} \mathrm{CO}_{3}$ & 35 \\
\hline 4 & $\mathrm{CH}_{2} \mathrm{Cl}_{2}$ & $\mathrm{Et}_{3} \mathrm{~N}$ & $\mathrm{NH}_{4} \mathrm{SCN}$ & $<2$ \\
\hline 5 & $\mathrm{CH}_{2} \mathrm{Cl}_{2}$ & $\mathrm{Et}_{3} \mathrm{~N}$ & aq $\mathrm{NH}_{4} \mathrm{OH}$ & 60 \\
\hline 6 & $\mathrm{CH}_{2} \mathrm{Cl}_{2}$ & NMM & aq $\mathrm{NH}_{4} \mathrm{OH}$ & 45 \\
\hline 7 & $\mathrm{CH}_{2} \mathrm{Cl}_{2}$ & DBU & aq $\mathrm{NH}_{4} \mathrm{OH}$ & 40 \\
\hline 8 & $\mathrm{CH}_{2} \mathrm{Cl}_{2}$ & DABCO & aq $\mathrm{NH}_{4} \mathrm{OH}$ & 30 \\
\hline 9 & $\mathrm{CH}_{2} \mathrm{Cl}_{2}$ & Pyridine & aq $\mathrm{NH}_{4} \mathrm{OH}$ & 58 \\
\hline 10 & $\mathrm{CH}_{2} \mathrm{Cl}_{2}$ & - & aq $\mathrm{NH}_{4} \mathrm{OH}$ & no reaction \\
\hline 11 & DCE & $\mathrm{Et}_{3} \mathrm{~N}$ & aq $\mathrm{NH}_{4} \mathrm{OH}$ & 30 \\
\hline 12 & $\mathrm{MeCN}$ & $\mathrm{Et}_{3} \mathrm{~N}$ & aq $\mathrm{NH}_{4} \mathrm{OH}$ & $<2$ \\
\hline 13 & $\mathrm{CH}_{2} \mathrm{Cl}_{2}\left(-10^{\circ} \mathrm{C}\right)$ & $\mathrm{Et}_{3} \mathrm{~N}$ & aq $\mathrm{NH}_{4} \mathrm{OH}$ & 65 \\
\hline 14 & $\mathrm{CH}_{2} \mathrm{Cl}_{2}\left(-78^{\circ} \mathrm{C}\right)$ & $\mathrm{Et}_{3} \mathrm{~N}$ & aq $\mathrm{NH}_{4} \mathrm{OH}$ & 68 \\
\hline
\end{tabular}

a Reaction conditions: benzoic acid (1 equiv) in anhydrous $\mathrm{CH}_{2} \mathrm{Cl}_{2}$ at $0{ }^{\circ} \mathrm{C}$, $\mathrm{Tf}_{2} \mathrm{O}$ (1.1 equiv), base (2.2 equiv) and ammonia source (2.5 equiv).

$1 \mathbf{a}$ in $60 \%$ isolated yield (entry 5 ). Focusing on this encouraging observation, we tried to optimize yields by evaluating the impact of different bases other than triethylamine $\left(\mathrm{Et}_{3} \mathrm{~N}\right)$. For this study, different organic bases such as NMM, pyridine, DBU and DABCO were used (entries 6-9) and pyridine was found to give the best yield compared to others (entry 9). Although pyridine and $\mathrm{Et}_{3} \mathrm{~N}$ (entries 5 and 9) gave comparable yields, reaction with $\mathrm{Et}_{3} \mathrm{~N}$ showed marginally better conversion with a shorter reaction time of $4 \mathrm{~h}$ compared to pyridine, which took $12 \mathrm{~h}$ for reaction to be complete. It was observed that the presence of a base is critical for acid into amide conversion, since there was no reaction in the absence of base (entry 10). With this understanding, we further studied the effect of solvent on reaction profile and yield. The reaction using solvents such as dichloroethane or acetonitrile afforded poor yields (entries 11 and 12) compared with dichloromethane. We could not use THF as a solvent as it polymerized when exposed to $\mathrm{Tf}_{2} \mathrm{O}$. A $10{ }^{\circ} \mathrm{C}$ drop in reaction temperature provided a better yield without compromising significantly the reaction rate (entries 13 vs. 5), although a further decrease in temperature to $-78{ }^{\circ} \mathrm{C}$ did not add any benefit (entry 14).

After optimization of reaction conditions, we determined the scope of this reaction using different carboxylic acids and tried to generalize the developed protocol (Scheme 1). It was observed that aromatic acids substituted 
with either electron-donating groups (1b, $\mathbf{1 c}, \mathbf{1 1}$ and $\mathbf{1 n})$ or electron-withdrawing groups (1d, 1g, 1i, $\mathbf{1 j}$ and $\mathbf{1 m}$ ) afforded good to excellent yields of the corresponding amides. The reaction also worked well and afforded good yields of primary amides with a range of aliphatic acids (1f, 1k, 1q) including racemic amino acids (1t, 1u, 1v, 1w and 1x). Furthermore, the three common amino group protecting groups (Boc, $\mathrm{Cbz}$ and $\mathrm{Fmoc}$ ) were found to be stable under these reaction conditions. The protocol was also found to be suitable for the synthesis of heteroaromatic (1e, 1p and 1s) and $\alpha, \beta$-unsaturated (10) carboxylic amides, as summarized in Scheme 1. In conclusion, triflic anhydride mediated conversion of acids into primary amides without any preactivation of the carboxyl group (e.g., as an acid chloride or mixed anhydride), demonstrated a broader substrate scope with some level of chemoselectivity. Although yields for acid into amide conversions fall short of being quantitative, the experimental simplicity of the process with mild reaction conditions, no need for pre-activation of the carboxylic acid and use of aqueous ammonium hydroxide as source of nitrogen are notable features of this protocol. There has been only one previous report involving direct conversion of carboxylic acids into primary amides at room temperature using aqueous ammonium hydroxide that employed ethyl chloroformate. ${ }^{16}$

After these promising results for primary amide synthesis, we attempted a $\mathrm{Tf}_{2} \mathrm{O}$ mediated one-pot conversion of carboxylic acids through to nitriles via the primary amides. This was based on the fact that $\mathrm{Tf}_{2} \mathrm{O}$ had been previously reported to promote conversion of primary amides into nitriles in the presence of an organic base. ${ }^{17}$ As a model reaction, benzoic acid was treated with 1.1 equivalents of $\mathrm{Tf}_{2} \mathrm{O}$ followed by addition of 2.2 equivalents of $\mathrm{Et}_{3} \mathrm{~N}$. The reaction mixture was stirred for 30 minutes and then aqueous ammonium hydroxide was introduced. The progress of the reaction was monitored by TLC and, once a maximum conversion into amide 1a was observed, an additional equivalent of $\mathrm{Tf}_{2} \mathrm{O}$ and $\mathrm{Et}_{3} \mathrm{~N}$ was introduced into the reaction mixture.

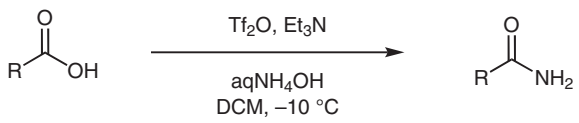<smiles>NC(=O)c1ccccc1</smiles>

$1 a, 70 \%$<smiles>COc1ccc(C(N)=O)cc1</smiles>

$1 b, 82 \%$<smiles>CN(C)c1ccc(C(N)=O)cc1</smiles>

$1 c, 67 \%$<smiles>NC(=O)c1ccc([N+](=O)[O-])cc1</smiles>

1d, $74 \%$<smiles>NC(=O)c1ccsc1</smiles>

1 e, $80 \%$<smiles>NC(=O)Cc1ccccc1</smiles>

1f, $66 \%$<smiles>CC(=O)c1ccc(C(N)=O)cc1</smiles>

1g, $76 \%$<smiles>CC(C)(C)OCc1ccc(C(N)=O)cc1</smiles>

1h, $82 \%$<smiles>NC(=O)c1ccc(F)cc1</smiles>

1i, $70 \%$<smiles>CNC(=O)c1ccc(C(N)=O)cc1</smiles>

$1 \mathrm{j}, 80 \%$<smiles>NC(=O)CCCc1c[nH]c2ccccc12</smiles>

$1 \mathrm{k}, 45 \%$<smiles>CN(C)c1cccc(C(N)=O)c1</smiles>

1 1 $71 \%$<smiles>N#Cc1ccc(C(N)=O)cc1</smiles>

$1 \mathrm{~m}, 78 \%$<smiles>NC(=O)c1ccc(OC(F)(F)F)cc1</smiles>

1n, $75 \%$<smiles>NC(=O)C=Cc1ccccc1</smiles>

$10,60 \%$<smiles>NC(=O)c1ccco1</smiles>

1p, $73 \%$

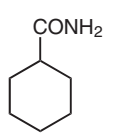

1q, $71 \%$

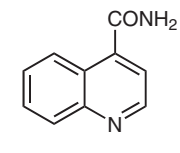

$1 \mathrm{r}, 56 \%$<smiles>NC(=O)c1ccc2c(c1)OCO2</smiles>

$1 \mathrm{~s}, 64 \%$<smiles>NC(=O)NC(Cc1ccccc1)C(N)=O</smiles>

$1 \mathrm{t}, 75 \%$

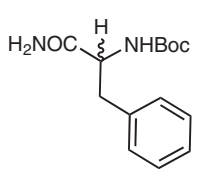

1u, $72 \%$

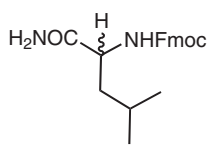

1v, $71 \%$

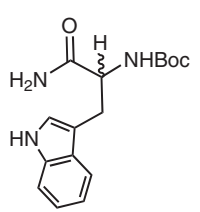

1w, $72 \%$

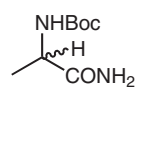

$1 x, 74 \%$

Scheme 1 Triflic anhydride mediated synthesis of primary amides. Reagents and conditions: acid ( 1 equiv) in anhydrous $\mathrm{CH}_{2} \mathrm{Cl}{ }_{2}$ at $-10{ }^{\circ} \mathrm{C}, \mathrm{Tf}_{2} \mathrm{O}(1.1$ equiv), $\mathrm{Et}_{3} \mathrm{~N}$ (2.2 equiv) and aqueous ammonium hydroxide (2.5 equiv). Substrates $\mathbf{1} \mathbf{t}-\mathbf{x}$ were used as their racemic mixture. 
This led to formation of benzonitrile, albeit in poor isolated yield of $42 \%$, after a reaction time of 5 hours (Table 2, entry 1 ). We tried to optimize reaction conditions by evaluating the role of the organic base. The use of pyridine, DIPEA and 2-chloropyridine resulted in sluggish reactions and poor yields of 2a (entries 2-5). ${ }^{1} \mathrm{H}$ NMR and TLC monitoring of the reaction mixture revealed that the additional equivalent of $\mathrm{Tf}_{2} \mathrm{O}$ was also promoting hydrolysis of the intermediate primary amide 1a back to the carboxylic acid. Unfortunately, all efforts to avoid this by introducing either molecular sieves or anhydrous sodium sulfate proved futile.

Table 2 Optimization Study for One-Pot Domino Conversion of Benzoic Acid $\mathbf{1}$ into Benzonitrile $\mathbf{2 a ^ { a }}$
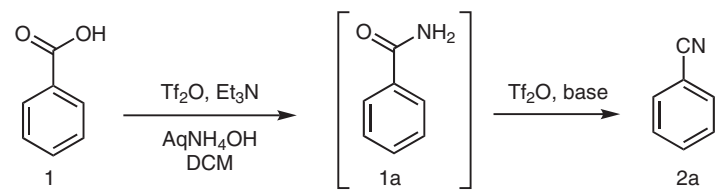

Entry Base for conversion Ammonia source Temp $\left({ }^{\circ} \mathrm{C}\right) \quad$ Yield of 2a (\%) of $1 \mathrm{a}$ into $2 \mathrm{a}$

\begin{tabular}{lllll}
\hline 1 & $\mathrm{Et}_{3} \mathrm{~N}$ & aq $\mathrm{NH}_{4} \mathrm{OH}$ & -10 & 42 \\
2 & $2-\mathrm{Cl}$ pyridine & aq $\mathrm{NH}_{4} \mathrm{OH}$ & -10 & - \\
3 & $2-\mathrm{Cl}$ pyridine & aq $\mathrm{NH}_{4} \mathrm{OH}$ & 40 & - \\
4 & DIPEA & aq $\mathrm{NH}_{4} \mathrm{OH}$ & -10 & 15 \\
5 & pyridine & aq $\mathrm{NH}_{4} \mathrm{OH}$ & -10 & 12 \\
6 & no base & aq $\mathrm{NH}_{4} \mathrm{OH}$ & -10 & 40 \\
7 & no base & aq $\mathrm{NH}_{4} \mathrm{OH}$ & 0 & 43 \\
\hline
\end{tabular}

a Reaction conditions: acid (1 equiv) in anhydrous $\mathrm{CH}_{2} \mathrm{Cl}_{2}, \mathrm{Tf}_{2} \mathrm{O}$ (1.1 equiv), $\mathrm{Et}_{3} \mathrm{~N}$ (2.2 equiv) and ammonium hydroxide ( 2.5 equiv) with addition of $\mathrm{Tf}_{2} \mathrm{O}$ (1.1 equiv) and base after amide $1 \mathrm{a}$ formation.

Therefore, we planned to overcome this by removal of the remaining water and solvent under reduced pressure before the addition of fresh $\mathrm{Tf}_{2} \mathrm{O}$ to induce amide into nitrile conversion. Thus, after solvent and residual water were removed after amide formation, anhydrous $\mathrm{CH}_{2} \mathrm{Cl}_{2}$ was introduced into the reaction flask followed by addition of $\mathrm{Tf}_{2} \mathrm{O}$ at low temperature to facilitate amide $\mathbf{1 a}$ into nitrile $\mathbf{2 a}$ conversion. However, no improvement in yield was observed. Interestingly, while an additional equivalent of $\mathrm{Tf}_{2} \mathrm{O}$ is necessary for amide into nitrile formation, we observed no need for further base addition after amide formation (Table 2 , entries 6 and 7). Attempts to perform the reaction with non-aqueous sources of ammonia such as ammonium carbonate, ammonium bicarbonate, ammonium chloride or ammonium thiocyanate were not fruitful due to slow rates of conversion and poor yields of amide. Various carboxylic acids such as acids substituted with electron-donating or electron-withdrawing groups, aliphatic acids and heteroaromatic acids were selected to screen the one-pot conversion of carboxylic acids into nitriles (Scheme 2). In this survey, the carboxylic acid of interest was dissolved in anhy- drous $\mathrm{CH}_{2} \mathrm{Cl}_{2}$. Triflic anhydride was added to this solution at $-10{ }^{\circ} \mathrm{C}$ followed by addition of $\mathrm{Et}_{3} \mathrm{~N}$ as base. The reaction was stirred for 30 minutes, aq. $\mathrm{NH}_{4} \mathrm{OH}$ was added and the reaction was monitored for formation of the corresponding amide. After maximum conversion of carboxylic acid into the corresponding amide, another equivalent of $\mathrm{Tf}_{2} \mathrm{O}$ was added to facilitate the formation of the nitrile.

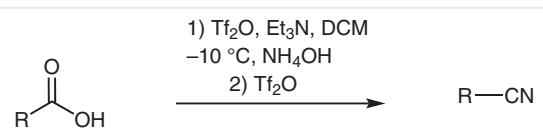

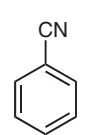

$2 a, 42 \%$

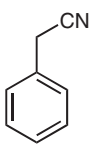

$2 f, 18 \%$

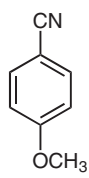

$2 b, 78 \%$<smiles>CN(C)c1ccc(C#N)cc1</smiles>

2c, $78 \%$

$2 d, 24 \%$<smiles>N#Cc1ccc([N+](=O)[O-])cc1</smiles><smiles>N#Cc1ccsc1</smiles>

$2 e, 20 \%$<smiles>CC(=O)c1ccc(C#N)cc1</smiles>

$2 \mathrm{~g}, 28 \%$<smiles>N#Cc1ccc(NC(=O)OCc2ccccc2)cc1</smiles>

$2 \mathrm{~h}, 22 \%$<smiles>N#Cc1ccc(F)cc1</smiles>

$2 \mathrm{i}, 18 \%$

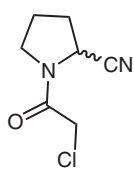

$3,30 \%$
Scheme 2 One-pot domino conversions of acids into nitriles. Reaction conditions: acid ( 1 equiv) in anhydrous $\mathrm{CH}_{2} \mathrm{Cl}_{2}$ at $-10{ }^{\circ} \mathrm{C}, \mathrm{Tf}_{2} \mathrm{O}(1.1$ equiv), $\mathrm{Et}_{3} \mathrm{~N}$ (2.2 equiv) and ammonium hydroxide (2.5 equiv) with addition of $\mathrm{Tf}_{2} \mathrm{O}$ (1.1 equiv) after amide formation.

Aromatic acids substituted with electron-donating groups afforded good yields of the corresponding nitriles (Scheme 2, products $\mathbf{2 b}$ and $\mathbf{2 c}$ ), but reaction with other substrates afforded poor yields of the product. This disappointing result prompted us to investigate $\mathrm{Tf}_{2} \mathrm{O}$ promoted amide into nitrile conversion. As a model substrate (Table 3 ), treatment of a $\mathrm{CH}_{2} \mathrm{Cl}_{2}$ solution of $\mathbf{1 a}$ with one equivalent of $\mathrm{Tf}_{2} \mathrm{O}$ afforded a good yield of nitrile $\mathbf{2 a}$ with or without the presence of an organic base (entries 1-3).

We found that triethylamine was not required for this conversion, unlike reported previously. ${ }^{17}$ We also explored the possibility of using other anhydride analogues of $\mathrm{Tf}_{2} \mathrm{O}$ such as mesyl anhydride $\left(\mathrm{Ms}_{2} \mathrm{O}\right)$ and trifluoroacetic anhydride (TFAA) (Table 3, entries 4-7). This led to the conclusion that $\mathrm{Tf}_{2} \mathrm{O}$ is a unique reagent for promoting amide into nitrile conversion in good yield. Even ethyl chloroformate (ClCOOEt), which has been previously found to be a good reagent to promote acid into primary amide conversion, ${ }^{16}$ did not work for amide into nitrile conversion under the given conditions (entries 8 and 9). Furthermore, $\mathrm{Tf}_{2} \mathrm{O}$ also demonstrated a wide substrate scope along with high level of chemoselectivity for amide into nitrile conversions, as demonstrated in Scheme 3. Reaction proceeded readily, with aromatic amides having an electron-donating group (Scheme 3; products $\mathbf{2 b}, \mathbf{2 c}, \mathbf{2 i}, \mathbf{2 s}, \mathbf{2 t}$ and $\mathbf{2 u}$ ) affording ex- 
Table 3 Screening of Reagents for Conversion of Benzamide 1a into Benzonitrile $2 \mathrm{a}^{\mathrm{a}}$

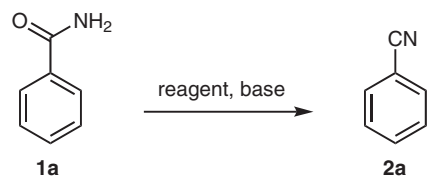

\begin{tabular}{lllll}
\hline Entry & Reagent & Base & Temp $\left({ }^{\circ} \mathrm{C}\right)$ & Yield $(\%)$ \\
\hline 1 & $\mathrm{Tf}_{2} \mathrm{O}$ & $\mathrm{Et}_{3} \mathrm{~N}$ & -10 & 82 \\
2 & $\mathrm{Tf}_{2} \mathrm{O}$ & - & -10 & 80 \\
3 & $\mathrm{Tf}_{2} \mathrm{O}$ & - & 0 & 85 \\
4 & $\mathrm{Ms}_{2} \mathrm{O}$ & - & -10 & - \\
5 & $\mathrm{Ms}_{2} \mathrm{O}$ & $\mathrm{Et}_{3} \mathrm{~N}$ & -10 & - \\
6 & $\mathrm{TFAA}$ & - & -10 & - \\
7 & $\mathrm{TFAA}$ & $\mathrm{Et}_{3} \mathrm{~N}$ & -10 & - \\
8 & $\mathrm{ClCOOEt}$ & - & -10 & - \\
9 & $\mathrm{ClCOOEt}$ & $\mathrm{Et}_{3} \mathrm{~N}$ & -10 & - \\
\hline
\end{tabular}

a Reaction conditions: amide (1 equiv) in anhydrous $\mathrm{CH}_{2} \mathrm{Cl}_{2}$, reagent (1.1 equiv) and $\mathrm{Et}_{3} \mathrm{~N}$ (2.2 equiv, if required).

cellent yields of the corresponding nitriles. Although the reaction with aromatic amides substituted with electronwithdrawing groups was sluggish, addition of 1 equivalent of $\mathrm{Et}_{3} \mathrm{~N}$ afforded the corresponding nitriles in very good yields ( $\mathbf{2 d}, \mathbf{2 g}, \mathbf{2} \mathbf{j}$ and $\mathbf{2 m}$ ). Reactions using heteroaromatic (2e, 2v and 2k) and aliphatic amides (2k, 2f, 2o, 2w, 2x, 2y and $\mathbf{2 z}$ ) also afforded excellent yields of the corresponding nitriles. In an evaluation of functional group tolerance and chemoselectivity of the developed protocol, it was observed that the conditions are compatible with a range of functional groups including ketones (2g), alkyl halides (2s), phenols $(\mathbf{2 t})$, alcohols (2u), amines (2r), and aldehydes (2p). Even acid-sensitive compounds such as $\mathbf{2 h}, \mathbf{2 x}$ and $\mathbf{2 z}$ (having Boc protecting groups) were found to be stable under these reaction conditions.

Finally to demonstrate the scalability of the developed protocols, we performed a synthesis of amide $\mathbf{1 b}$ and nitrile $\mathbf{2 b}$ at $1 \mathrm{~g}$ scale. In gram-scale experiments, the two desired products were obtained in good yields $74 \%$ and $78 \%$ isolated yields, respectively) and high chemical purity after standard work-up without need for column chromatography.

In conclusion, we have demonstrated a facile conversion of a broad range of carboxylic acids into their corresponding amides by employing aqueous ammonium hydroxide as a source of nitrogen and using trifluoromethanesulfonic anhydride $\left(\mathrm{Tf}_{2} \mathrm{O}\right)$ as a promoter. We also observed that $\mathrm{Tf}_{2} \mathrm{O}$ can facilitate amide into nitrile conversion with high functional group tolerance in good to excellent yields. In conclusion, $\mathrm{Tf}_{2} \mathrm{O}$ is found to be the unique promoter for stepwise, two-pot conversion of carboxylic acids into their respective nitriles by using aqueous ammonium hydroxide as a source of nitrogen. The methodology is practically simple, robust, versatile, and works well with substrates having acid-labile functional groups. However, it is disappointing to see limited success of this methodology for one-pot domino conversion of acids into nitriles due to poor yields.

Reagents and starting materials were obtained from commercial sources and used as received. The solvents were purified and dried by standard procedures prior to use. All reactions were performed under an inert atmosphere. Flash chromatography was carried out using silica gel (100-200 mesh). Thin-layer chromatography was performed on silica gel plates (Merck) and plates were visualized by staining with $\mathrm{KMnO}_{4} \cdot{ }^{1} \mathrm{H}$ and ${ }^{13} \mathrm{C}$ NMR spectra were recorded either with a Bruker Avance DPX $400\left(400 \mathrm{MHz}\right.$ for ${ }^{1} \mathrm{H}$ and $100 \mathrm{MHz}$ for ${ }^{13} \mathrm{C}$ ) or Bruker Avance 300 ( $300 \mathrm{MHz}$ for ${ }^{1} \mathrm{H}$ and $75 \mathrm{MHz}$ for ${ }^{13} \mathrm{C}$ ) spectrometer in $\mathrm{CDCl}_{3}$, DMSO- $d_{6}$ or acetone- $d_{6}$ using TMS as internal standard. Chemical shifts $(\delta)$ for ${ }^{1} \mathrm{H}$ and ${ }^{13} \mathrm{C}$ are given in ppm and coupling constants are given in $\mathrm{Hz}$. The following abbreviations are used to indicate peak multiplicity: s, singlet; d, doublet; t, triplet; q, quartet; $\mathrm{m}$, multiplet; br. s, broad signal. Mass spectra were recorded with an Advion Mass Express CMS instrument. HRMS spectra were recorded with an Orbitrap Fusion mass spectrometer (Thermo) in positive ion mode through direct infusion by syringe. Evaporation of solvents was performed under reduced pressure with a Büchi rotary evaporator.

\section{General Procedure for Screening of Conditions (Table 1)}

To a solution of carboxylic acid ( $1 \mathrm{mmol})$ in $\mathrm{CH}_{2} \mathrm{Cl}_{2}(10 \mathrm{~mL})$ at $0{ }^{\circ} \mathrm{C}$ was added $\mathrm{Tf}_{2} \mathrm{O}(1.1 \mathrm{mmol})$ followed by addition of base $(0.31 \mathrm{~mL}, 2.2$ $\mathrm{mmol})$. The reaction mixture was stirred for an additional 30 minutes at the same temperature before the addition of the ammonium source $(2.5 \mathrm{mmol})$. Progress of the reaction was monitored by TLC. After $4 \mathrm{~h}$, the reaction mixture was diluted with $\mathrm{CH}_{2} \mathrm{Cl}_{2}(20 \mathrm{~mL})$ and washed with $1 \mathrm{M}$ aq $\mathrm{HCl}(10 \mathrm{~mL})$, followed by aq. $\mathrm{NaHCO}_{3}(10 \mathrm{~mL})$ and then brine $(10 \mathrm{~mL})$. The organic layer was dried over anhydrous sodium sulfate, filtered and concentrated under reduced pressure to give the desired product. If required, further purification was carried out using flash column chromatography, eluting with EtOAc-hexane.

\section{General Procedure for Synthesis of Amides from Carboxylic Acids} (Scheme 1)

To a solution of the carboxylic acid $(1 \mathrm{mmol})$ in $\mathrm{CH}_{2} \mathrm{Cl}_{2}(10 \mathrm{~mL})$ at $-10{ }^{\circ} \mathrm{C}$ was added $\mathrm{Tf}_{2} \mathrm{O}(0.19 \mathrm{~mL}, 1.1 \mathrm{mmol})$ followed by $\mathrm{Et}_{3} \mathrm{~N}(0.31$ $\mathrm{mL}, 2.2 \mathrm{mmol}$ ). The reaction mixture was stirred for an additional 30 minutes at the same temperature before the addition of aqueous ammonium hydroxide ( $2.5 \mathrm{mmol} ; 28 \%$ in water). Progress of the reaction was monitored by TLC. After $4 \mathrm{~h}$, the reaction mixture was diluted with $\mathrm{CH}_{2} \mathrm{Cl}_{2}(20 \mathrm{~mL})$ and washed with $1 \mathrm{M}$ aq $\mathrm{HCl}(10 \mathrm{~mL})$, followed by aq $\mathrm{NaHCO}_{3}(10 \mathrm{~mL})$ and then brine $(10 \mathrm{~mL})$. The organic layer was dried over anhydrous sodium sulfate, filtered and concentrated under reduced pressure to furnish the desired product. If required, further purification was carried out using flash column chromatography, eluting with EtOAc-hexane.

\section{Procedure for Scale-up Synthesis of $\mathbf{1 b}$ from Benzoic Acid}

To a solution of benzoic acid ( $1 \mathrm{~g}, 6.57 \mathrm{mmol})$ in $\mathrm{CH}_{2} \mathrm{Cl}_{2}(25 \mathrm{~mL})$ at $-10{ }^{\circ} \mathrm{C}$ was added $\mathrm{Tf}_{2} \mathrm{O}(1.21 \mathrm{~mL}, 7.23 \mathrm{mmol})$ followed by $\mathrm{Et}_{3} \mathrm{~N}(2.03$ $\mathrm{mL}, 14.4 \mathrm{mmol}$ ). The reaction mixture was stirred for an additional 30 minutes at the same temperature before the addition of aqueous ammonium hydroxide ( $2.5 \mathrm{mmol} ; 28 \%$ in water). Progress of the reaction was monitored by TLC. After $4 \mathrm{~h}$, reaction mixture was diluted with $\mathrm{CH}_{2} \mathrm{Cl}_{2}(90 \mathrm{~mL})$ and washed with $1 \mathrm{M}$ aq $\mathrm{HCl}(20 \mathrm{~mL})$, followed by aq 
<smiles>N#Cc1ccccc1</smiles>

2a, $85 \%$<smiles>CC(=O)c1ccc(C#N)cc1</smiles><smiles>N#Cc1ccc(NC(=O)c2ccccc2)cc1</smiles>

$2 g, 72 \%$<smiles>N#Cc1ccc(C#N)cc1</smiles>

$2 \mathrm{~m}, 76 \%$<smiles>N#Cc1ccc(CBr)cc1</smiles>

2s, $88 \%$

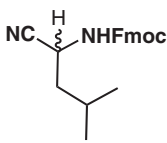

$2 y, 72 \%$

$80 \%$

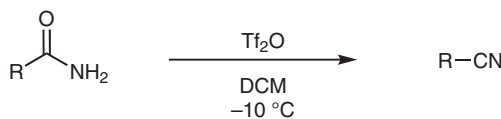<smiles>COc1ccc(C#N)cc1</smiles><smiles>CN(C)c1ccc(C#N)cc1</smiles><smiles>N#Cc1ccc([N+](=O)[O-])cc1</smiles><smiles>N#Cc1ccsc1</smiles><smiles>N#CCc1ccccc1</smiles>

$2 e, 80 \%$

2f, $85 \%$<smiles>CCCCc1c[nH]c2ccccc12</smiles>

$2 k, 74 \%$

$21,80 \%$<smiles>N#Cc1ccc([N+](=O)[O-])cc1</smiles><smiles>N#Cc1ccc(N)cc1</smiles>

$2 q, 83 \%$

2 r, $82 \%$

2o, $67 \%$

$2 p, 80 \%$<smiles>N#Cc1ccc(CO)cc1</smiles>

NC<smiles>N#CC(Cc1ccccc1)NCCN</smiles>

$2 \mathrm{w}, 76 \%$<smiles>N#CC(Cc1ccccc1)NC(=O)OCc1ccccc1</smiles>

$2 x, 78 \%$
$2 \mathrm{u}, 84 \%$

$2 v, 72 \%$

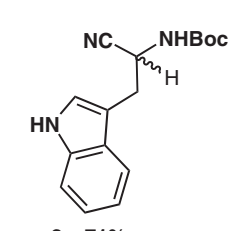

2z, $71 \%$

Scheme 3 Substrate scope for reaction of amide into nitrile conversion. Reaction conditions: Amide (1 equiv) was dissolved in $\mathrm{CH}_{2} \mathrm{Cl}_{2}$ and cooled to $-10{ }^{\circ} \mathrm{C}$. To this solution was added $\mathrm{Tf}_{2} \mathrm{O}$ (1.1 equiv). An addition of $\mathrm{Et}_{3} \mathrm{~N}$ (2.2 equiv) was required for $\mathbf{2 d}, \mathbf{2} \mathbf{g}, \mathbf{2 j}, \mathbf{2} \mathbf{m}, \mathbf{2} \mathbf{h}, \mathbf{2}$, and $\mathbf{2 z}$. The substrates $\mathbf{2} \mathbf{w}-\mathbf{z}$ were used as their racemate.

$\mathrm{NaHCO}_{3}(20 \mathrm{~mL})$ and then brine $(20 \mathrm{~mL})$. The organic layer was dried over anhydrous sodium sulfate, filtered and concentrated under reduced pressure to obtain 1a, which was used further without any purification (730 mg, 74\%).

\section{Benzamide (1a)}

The title compound was prepared following the general procedure for synthesis of amides from carboxylic acids. It was isolated as a white solid (85 mg, 70\%).

$\left.{ }^{1} \mathrm{H} \mathrm{NMR} \mathrm{(300} \mathrm{MHz,} \mathrm{CDCl}_{3}\right): \delta=7.81(\mathrm{~d}, J=7.2 \mathrm{~Hz}, 2 \mathrm{H}), 7.55-7.41(\mathrm{~m}$, $3 \mathrm{H}), 6.22$ (br s, $2 \mathrm{H})$.

The analytical data were found to be consistent with the literature. ${ }^{18}$

${ }^{1} \mathrm{H}$ NMR (400 MHz, DMSO- $d_{6}$ ): $\delta=7.72(\mathrm{~d}, J=8.8 \mathrm{~Hz}, 2 \mathrm{H}$ ), 7.62 (br s,

\section{4-Methoxybenzamide (1b)}

The title compound was prepared following the general procedure for synthesis of amides from carboxylic acids. It was isolated as a white solid (124 mg, 82\%).

${ }^{1} \mathrm{H}$ NMR (400 MHz, DMSO- $d_{6}$ ): $\delta=7.84$ (d, $J=8.8 \mathrm{~Hz}, 3 \mathrm{H}$ ), 7.19 (br s, $1 \mathrm{H}), 6.98$ (d, $J=8.8 \mathrm{~Hz}, 2 \mathrm{H}), 3.75(\mathrm{~s}, 3 \mathrm{H})$.

The analytical data were found to be consistent with the literature. ${ }^{18}$

\section{4-(Dimethylamino)benzamide (1c)}

The title compound was prepared following the general procedure for synthesis of amides from carboxylic acids. It was isolated as an off white solid (110 mg, 67\%). 
The analytical data were found to be consistent with the literature. ${ }^{19}$

\section{4-Nitrobenzamide (1d)}

The title compound was prepared following the general procedure for synthesis of amides from carboxylic acid.s It was isolated as a yellow solid (123 mg, 74\%).

${ }^{1} \mathrm{H}$ NMR (400 MHz, DMSO- $d_{6}$ ): $\delta=8.32-8.30(\mathrm{~m}, 3 \mathrm{H}), 8.10(\mathrm{~d}, J=$ $8.4 \mathrm{~Hz}, 2 \mathrm{H}$ ), 7.74 (br s, $1 \mathrm{H}$ ).

The analytical data were found to be consistent with the literature. ${ }^{18}$

\section{Thiophene-3-carboxamide (1e)}

The title compound was prepared following the general procedure for synthesis of amides from carboxylic acids. It was isolated as a white solid (102 mg, 80\%).

${ }^{1} \mathrm{H}$ NMR (400 MHz, DMSO- $d_{6}$ ): $\delta=8.11-8.10(\mathrm{~m}, 1 \mathrm{H}), 7.78(\mathrm{~s}, 1 \mathrm{H})$, 7.55-7.53 (m, $1 \mathrm{H}), 7.4-7.45$ (m, $1 \mathrm{H}), 7.21$ (br s, $1 \mathrm{H})$.

The analytical data were found to be consistent with the literature. ${ }^{20}$

\section{2-Phenylacetamide (1f)}

The title compound was prepared following the general procedure for synthesis of amides from carboxylic acids. It was isolated as a white solid (89 mg, 66\%).

${ }^{1} \mathrm{H}$ NMR (400 MHz, DMSO- $d_{6}$ ): $\delta=7.45$ (br s, $1 \mathrm{H}$ ), 7.30-7.21 (m, $5 \mathrm{H}$ ), 6.85 (br s, $1 \mathrm{H}$ ), 3.36 (s, $2 \mathrm{H}$ ).

The analytical data were found to be consistent with the literature. ${ }^{18}$

\section{4-Acetylbenzamide (1g)}

The title compound was prepared following the general procedure for synthesis of amides from carboxylic acids. It was isolated as a white solid (124 mg, 76\%).

${ }^{1} \mathrm{H}$ NMR (300 MHz, DMSO- $\left.d_{6}\right): \delta=8.14$ (br s, $1 \mathrm{H}$ ), 8.02-7.96 (m, $4 \mathrm{H}$ ), 7.56 (br s, $1 \mathrm{H}), 2.61$ (s, $3 \mathrm{H}$ ).

The analytical data were found to be consistent with the literature. ${ }^{20}$

\section{tert-Butyl (4-Carbamoylphenyl)carbamate (1h)}

The title compound was prepared following the general procedure for synthesis of amides from carboxylic acids. It was isolated as a white solid (194 mg, 82\%).

${ }^{1} \mathrm{H}$ NMR (300 MHz, DMSO- $d_{6}$ ): $\delta=9.60$ (br s, $\left.1 \mathrm{H}\right), 7.77$ (d, $J=8.4 \mathrm{~Hz}$, $3 \mathrm{H}), 7.49$ (d, $J=8.1 \mathrm{~Hz}, 2 \mathrm{H}), 7.18$ (br s, $1 \mathrm{H}), 1.48$ (s, $9 \mathrm{H}$ ).

The analytical data were found to be consistent with the literature. ${ }^{21}$

\section{4-Fluorobenzamide (1i)}

The title compound was prepared following the general procedure for synthesis of amides from carboxylic acids. It was isolated as an off white solid (97 mg, 70\%).

${ }^{1} \mathrm{H}$ NMR $\left(300 \mathrm{MHz}, \mathrm{CDCl}_{3}\right): \delta=7.87-7.82(\mathrm{~m}, 2 \mathrm{H}), 7.13(\mathrm{t}, J=8.7 \mathrm{~Hz}$, $2 \mathrm{H}), 6.07-5.88$ (br s, $2 \mathrm{H}$ ).

The analytical data were found to be consistent with the literature. ${ }^{22}$

\section{$\mathbf{N}, \mathbf{N}$-Dimethylterephthalamide (1j)}

The title compound was prepared following the general procedure for synthesis of amides from carboxylic acids. It was isolated as a yellow solid (154 mg, 80\%).
${ }^{1} \mathrm{H}$ NMR $\left(300 \mathrm{MHz}, \mathrm{CDCl}_{3}\right): \delta=7.82(\mathrm{~d}, J=7.5 \mathrm{~Hz}, 2 \mathrm{H}), 7.47(\mathrm{~d}, J=$ $7.8 \mathrm{~Hz}, 2 \mathrm{H}$ ), 6.24 (br s, 1 H), 5.72 (br s, $1 \mathrm{H}$ ), 3.12 (s, $3 \mathrm{H}$ ), 2.95 (s, $3 \mathrm{H}$ ). ${ }^{13} \mathrm{C}$ NMR $\left(75 \mathrm{MHz}, \mathrm{CDCl}_{3}\right): \delta=35.3,39.3,127.2,127.6,134.4,139.6$, 168.7, 170.67 .

HRMS (APCI): $m / z$ [M $+\mathrm{H}]^{+}$calcd for $\mathrm{C}_{10} \mathrm{H}_{12} \mathrm{~N}_{2} \mathrm{O}_{2}$ : 193.0975; found: 193.0972.

\section{3-Indolylbutyramide (1k)}

The title compound was prepared following the general procedure for synthesis of amides from carboxylic acids. It was isolated as an off white solid (91 mg, 45\%).

${ }^{1} \mathrm{H}$ NMR $\left(300 \mathrm{MHz}\right.$, DMSO- $\left.d_{6}\right): \delta=7.50(\mathrm{~d}, J=7.8 \mathrm{~Hz}, 2 \mathrm{H}), 7.32(\mathrm{~d}, J=$ $7.8 \mathrm{~Hz}, 2 \mathrm{H}$ ), 7.26 (br s, $1 \mathrm{H}$ ), 7.10-6.94 (m, $3 \mathrm{H}$ ), 6.71 (br s, $1 \mathrm{H}), 2.67$ $(\mathrm{t}, J=7.2 \mathrm{~Hz}, 2 \mathrm{H}), 2.12(\mathrm{t}, J=7.2 \mathrm{~Hz}, 2 \mathrm{H}), 1.90-1.83(\mathrm{~m}, 2 \mathrm{H})$.

The analytical data were found to be consistent with the literature. ${ }^{23}$

\section{3-(Dimethylamino)benzamide (11)}

The title compound was prepared following the general procedure for synthesis of amides from carboxylic acids. It was isolated as a lightbrown solid (117 $\mathrm{mg}, 71 \%$ ).

${ }^{1} \mathrm{H}$ NMR $\left(300 \mathrm{MHz}, \mathrm{CDCl}_{3}\right): \delta=7.32-7.25(\mathrm{~m}, 2 \mathrm{H}), 7.04(\mathrm{~d}, J=7.2 \mathrm{~Hz}$, $2 \mathrm{H}), 6.88(\mathrm{~d}, J=8.1 \mathrm{~Hz}, 2 \mathrm{H}), 6.13(\mathrm{~s}, 1 \mathrm{H}), 5.90(\mathrm{~s}, 1 \mathrm{H}), 3.02(\mathrm{~s}, 6 \mathrm{H})$.

The analytical data were found to be consistent with the literature. ${ }^{24}$

\section{4-Cyanobenzamide (1m)}

The title compound was prepared following the general procedure for synthesis of amides from carboxylic acids. It was isolated as an off white solid (115 mg, 78\%).

${ }^{1} \mathrm{H}$ NMR $\left(300 \mathrm{MHz}\right.$, DMSO- $\left.d_{6}\right): \delta=8.21($ br s, $1 \mathrm{H}), 8.02(\mathrm{~d}, J=8.4 \mathrm{~Hz}$, $2 \mathrm{H}), 7.95$ (d, $J=8.4 \mathrm{~Hz}, 2 \mathrm{H}), 7.68$ (br s, $1 \mathrm{H})$.

The analytical data were found to be consistent with the literature. ${ }^{25}$

\section{4-Trifluoromethoxy Benzamide (1n)}

The title compound was prepared following the general procedure for synthesis of amides from carboxylic acids. It was isolated as a white solid (154 mg, 75\%). ${ }^{1} \mathrm{H}$ NMR (400 MHz, DMSO- $\left.d_{6}\right): \delta=8.07(1 \mathrm{H}, \mathrm{s})$, 7.99 (d, J = 8.8 Hz, 2 H), 7.49 (br s, 1 H), 7.45 (d, J = 8.0 Hz, 2 H).

The analytical data were found to be consistent with the literature. ${ }^{26}$

\section{Cinnamamide (10)}

The title compound was prepared following the general procedure for synthesis of amides from carboxylic acids. It was isolated as a white solid (89 mg, 60\%).

${ }^{1} \mathrm{H}$ NMR $\left(300 \mathrm{MHz}, \mathrm{CDCl}_{3}\right): \delta=7.64(\mathrm{~d}, J=15.9 \mathrm{~Hz}, 1 \mathrm{H}), 7.50(\mathrm{br} \mathrm{s}$, $2 \mathrm{H}), 7.36$ (br s, $3 \mathrm{H}), 6.65$ (d, $J=15.6 \mathrm{~Hz}, 1 \mathrm{H}), 5.74$ (br s, $2 \mathrm{H}$ ).

The analytical data were found to be consistent with the literature. ${ }^{20}$

\section{2-Furoamide (1p)}

The title compound was prepared following the general procedure for synthesis of amides from carboxylic acids. It was isolated as a white solid (81 mg, 73\%).

${ }^{1} \mathrm{H}$ NMR $\left(300 \mathrm{MHz}\right.$, DMSO- $\left.d_{6}\right): \delta=7.79(\mathrm{~d}, J=7.8 \mathrm{~Hz}, 1 \mathrm{H}), 7.76(\mathrm{br} \mathrm{s}$, $1 \mathrm{H}), 7.36$ (br s, $1 \mathrm{H}), 7.08$ (d, $J=7.8 \mathrm{~Hz}, 1 \mathrm{H}), 6.59(\mathrm{~m}, 1 \mathrm{H})$.

The analytical data were found to be consistent with the literature. ${ }^{18}$ 


\section{Cyclohexanecarboxamide (1q)}

The title compound was prepared following the general procedure for synthesis of amides from carboxylic acids. It was isolated as a white solid (91 mg, 71\%).

${ }^{1} \mathrm{H}$ NMR (300 MHz, $\mathrm{CDCl}_{3}$ ): $\delta=5.48$ (br s, $2 \mathrm{H}$ ), 2.15 (m, $1 \mathrm{H}$ ), 1.671.91 ( $\mathrm{m}, 5 \mathrm{H}), 1.17-1.47$ ( $\mathrm{m}, 5 \mathrm{H})$.

The analytical data were found to be consistent with the literature. ${ }^{27}$

\section{4-Quinolinecarboxamide (1r)}

The title compound was prepared following the general procedure for synthesis of amides from carboxylic acids. It was isolated as a white solid (98 mg, 56\%).

${ }^{1} \mathrm{H}$ NMR $\left(300 \mathrm{MHz}\right.$, DMSO- $\left.d_{6}\right): \delta=8.99(\mathrm{~d}, J=4.2 \mathrm{~Hz}, 1 \mathrm{H}), 8.24(\mathrm{~d}, J=$ $7.8 \mathrm{~Hz}, 1 \mathrm{H}), 8.10(\mathrm{~d}, J=8.4 \mathrm{~Hz}, 1 \mathrm{H}), 7.93(\mathrm{~s}, 1 \mathrm{H}), 7.82-7.87(\mathrm{~m}, 1 \mathrm{H})$, 7.68-7.73 (m, $1 \mathrm{H}), 7.59(\mathrm{~d}, J=4.2 \mathrm{~Hz}, 1 \mathrm{H})$.

The analytical data were found to be consistent with the literature. ${ }^{28}$

\section{Benzo[d][1,3]dioxole-5-carboxamide (1s)}

The title compound was prepared following the general procedure for synthesis of amides from carboxylic acids. It was isolated as an offwhite solid (106 mg, 64\%).

${ }^{1} \mathrm{H}$ NMR (300 MHz, DMSO- $d_{6}$ ): $\delta=7.80$ (br s, $1 \mathrm{H}$ ), 7.47 (dd, $J=9.9$, $1.8 \mathrm{~Hz}, 1 \mathrm{H}), 7.39$ (d, J =1.8 Hz, $1 \mathrm{H}$ ), 7.22 (br s, $1 \mathrm{H}), 6.96$ (d, $J=8.1 \mathrm{~Hz}$, $1 \mathrm{H}), 6.08$ (s, $2 \mathrm{H})$.

The analytical data were found to be consistent with the literature. ${ }^{29}$

\section{Benzyl (1-Amino-1-oxo-3-phenylpropan-2-yl)carbamate (1t)}

The title compound was prepared following the general procedure for synthesis of amides from carboxylic acids. It was isolated as a white solid (225 mg, 75\%).

${ }^{1} \mathrm{H}$ NMR (300 MHz, DMSO- $\left.d_{6}\right): \delta=7.18-7.42(\mathrm{~m}, 12 \mathrm{H}), 7.06(\mathrm{~s}, 1 \mathrm{H})$, 4.93 (s, $2 \mathrm{H}), 4.15-4.16(\mathrm{~m}, 1 \mathrm{H}), 2.97-3.00(\mathrm{~m}, 1 \mathrm{H}), 2.69-2.76(\mathrm{~m}$, $1 \mathrm{H})$.

The analytical data were found to be consistent with the literature. ${ }^{30}$

\section{tert-Butyl (1-Amino-1-oxo-3-phenylpropan-2yl)carbamate (1u)}

The title compound was prepared following the general procedure for synthesis of amides from carboxylic acids. It was isolated as a white solid (192 mg, 72\%).

${ }^{1} \mathrm{H}$ NMR (300 MHz, DMSO- $d_{6}$ ): $\delta=7.36$ (br s, $1 \mathrm{H}$ ), 7.22-7.30 (m, $5 \mathrm{H}$ ), 7.00 (br s, $1 \mathrm{H}), 6.81(\mathrm{~d}, J=6.6 \mathrm{~Hz}, 1 \mathrm{H}), 4.09(\mathrm{~m}, 1 \mathrm{H}), 2.97$ (dd, $J=$ 13.8, $1 \mathrm{H}), 2.75(\mathrm{dd}, J=13.7,1 \mathrm{H}), 1.30(\mathrm{~s}, 9 \mathrm{H})$.

The analytical data found to be consistent with literature. ${ }^{31}$

\section{(9H-Fluoren-9-yl) Methyl (1-Amino-4-methyl-1-oxopentan-2- yl)carbamate (1v)}

The title compound was prepared following the general procedure for synthesis of amides from carboxylic acids. It was isolated as a white solid (252 mg, 71\%).

${ }^{1} \mathrm{H}$ NMR (300 MHz, DMSO- $d_{6}$ ): $\delta$ = 7.29-7.89 (m, $9 \mathrm{H}$ ), $6.95(\mathrm{~s}, 1 \mathrm{H})$, 4.20-4.30 (m, $3 \mathrm{H}), 3.95$ (m, $1 \mathrm{H}), 1.48-1.39$ (m, $3 \mathrm{H}), 0.85$ (m, $6 \mathrm{H})$.

MS (APCl+): $m / z=353.22[\mathrm{M}+\mathrm{H}]^{+}$.

The analytical data were found to be consistent with the literature. ${ }^{32}$

\section{tert-Butyl (1-Amino-3-(1H-indol-3-yl)-1-oxopropan-2yl) carba-} mate (1w)

The title compound was prepared following the general procedure for synthesis of amides from carboxylic acids. It was isolated as a white solid (219 mg, 72\%).

${ }^{1} \mathrm{H}$ NMR (300 MHz, DMSO- $\left.d_{6}\right): \delta=10.79(\mathrm{~s}, 1 \mathrm{H}), 7.61(\mathrm{~d}, J=7.8 \mathrm{~Hz}$, $1 \mathrm{H}), 7.30-7.36(\mathrm{~m}, 2 \mathrm{H}), 6.94-7.11(\mathrm{~m}, 4 \mathrm{H}), 6.66(\mathrm{~d}, J=8.1 \mathrm{~Hz}, 1 \mathrm{H})$, 4.01-4.12 (m, $1 \mathrm{H}), 3.09(\mathrm{~d}, J=3.3 \mathrm{~Hz}, 1 \mathrm{H}), 2.92(\mathrm{~m}, 1 \mathrm{H}), 1.31(\mathrm{~s}, 9 \mathrm{H})$. The analytical data were found to be consistent with the literature. ${ }^{33}$

\section{tert-Butyl (1-Amino-1-oxopropan-2-yl)carbamate or Boc-Alanine} Amide (1x)

The title compound was prepared following the general procedure for synthesis of amides from carboxylic acids. It was isolated as a white solid (140 mg, 74\%).

${ }^{1} \mathrm{H}$ NMR (300 MHz, DMSO- $d_{6}$ ): $\delta=7.20$ (br s, $1 \mathrm{H}$ ), 6.90 (br s, $1 \mathrm{H}$ ), 6.76 $(\mathrm{d}, J=7.2 \mathrm{~Hz}, 1 \mathrm{H}), 3.88(\mathrm{q}, J=7.5 \mathrm{~Hz}, 1 \mathrm{H}), 1.37(\mathrm{~s}, 9 \mathrm{H}), 1.17(\mathrm{~d}, J=$ $7.2 \mathrm{~Hz}, 3 \mathrm{H})$.

The analytical data were found to be consistent with the literature. ${ }^{34}$

\section{General Procedure for Optimization Studies (Table 2)}

To a solution of carboxylic acid $(1 \mathrm{mmol})$ in $\mathrm{CH}_{2} \mathrm{Cl}_{2}(10 \mathrm{~mL})$ at $-10{ }^{\circ} \mathrm{C}$ was added $\mathrm{Tf}_{2} \mathrm{O}(0.19 \mathrm{~mL}, 1.1 \mathrm{mmol})$ followed by base $(2.2 \mathrm{mmol})$. The reaction mixture was stirred for an additional 30 minutes at the same temperature before the addition of ammonium hydroxide $(2.5 \mathrm{mmol})$. Progress of the reaction was monitored by TLC for amide formation. After $4 \mathrm{~h}$, one more equivalent of triflic anhydride $(0.19 \mathrm{~mL}, 1.1$ mmol) was introduced. After $4 \mathrm{~h}$, the reaction mixture was diluted with $\mathrm{CH}_{2} \mathrm{Cl}_{2}(20 \mathrm{~mL})$ and washed with $1 \mathrm{M}$ aq $\mathrm{HCl}(10 \mathrm{~mL})$, followed by aq $\mathrm{NaHCO}_{3}(10 \mathrm{~mL})$ and then brine $(10 \mathrm{~mL})$. The organic layer was dried over anhydrous sodium sulfate, filtered and concentrated under reduced pressure to give the desired product. The product was purified by flash column chromatography eluting with EtOAc-hexane.

\section{General Procedure for Synthesis of Nitriles from Carboxylic Acids} (Scheme 2)

To a solution of carboxylic acid $(1 \mathrm{mmol})$ in $\mathrm{CH}_{2} \mathrm{Cl}_{2}(10 \mathrm{~mL})$ at $-10{ }^{\circ} \mathrm{C}$ was added $\mathrm{Tf}_{2} \mathrm{O}(0.19 \mathrm{~mL}, 1.1 \mathrm{mmol})$ followed by $\mathrm{Et}_{3} \mathrm{~N}(0.31 \mathrm{~mL}, 2.2$ $\mathrm{mmol}$ ). The reaction mixture was stirred for an additional 30 minutes at the same temperature before the addition of ammonium hydroxide ( $2.5 \mathrm{mmol}$ ). Progress of the reaction was monitored by TLC for amide formation. After $4 \mathrm{~h}$, one more equivalent of triflic anhydride $(0.19$ $\mathrm{mL}, 1.1 \mathrm{mmol}$ ) was introduced. After $4 \mathrm{~h}$, reaction mixture was diluted with $\mathrm{CH}_{2} \mathrm{Cl}_{2}(20 \mathrm{~mL})$ and washed with $1 \mathrm{M} \mathrm{aq} \mathrm{HCl}(10 \mathrm{~mL})$, followed by aq $\mathrm{NaHCO}_{3}$ solution $(10 \mathrm{~mL})$ and then brine $(10 \mathrm{~mL})$. The organic layer was dried over anhydrous sodium sulfate, filtered and concentrated under reduced pressure. The residue was purified by flash column chromatography, eluting with EtOAc-hexane.

\section{Benzonitrile (2a)}

The title compound was prepared following the general procedure for synthesis of nitriles from carboxylic acids. It was isolated as a colorless liquid (43 mg, 42\%).

${ }^{1} \mathrm{H}$ NMR (300 MHz, $\left.\mathrm{CDCl}_{3}\right): \delta=7.66-7.57(\mathrm{~m}, 3 \mathrm{H}), 7.48-7.44(\mathrm{~m}, 2 \mathrm{H})$. The analytical data were found to be consistent with the literature. ${ }^{35}$ 


\section{4-Methoxybenzonitrile (2b)}

The title compound was prepared following the general procedure for synthesis of nitriles from carboxylic acids. It was isolated as an off white solid (104 mg, 78\%).

${ }^{1} \mathrm{H}$ NMR $\left(400 \mathrm{MHz}, \mathrm{CDCl}_{3}\right): \delta=7.60(\mathrm{~d}, J=8.8 \mathrm{~Hz}, 2 \mathrm{H}), 6.96(\mathrm{~d}, J=$ $9.24 \mathrm{~Hz}, 2 \mathrm{H}), 3.87$ (s, $3 \mathrm{H})$.

The analytical data were found to be consistent with the literature. ${ }^{35}$

\section{4-Dimethylamino-benzonitrile (2c)}

The title compound was prepared following the general procedure for synthesis of nitrile from carboxylic acid. It was isolated as an off white solid (114 mg, 78\%).

${ }^{1} \mathrm{H}$ NMR (400 MHz, $\left.\mathrm{CDCl}_{3}\right): \delta=7.51(\mathrm{~d}, J=8.8 \mathrm{~Hz}, 2 \mathrm{H}), 6.79(\mathrm{~d}, J=$ $8.8 \mathrm{~Hz}, 2 \mathrm{H}), 3.05(\mathrm{~s}, 6 \mathrm{H})$

The analytical data found to be consistent with literature. ${ }^{35}$

\section{4-Nitrobenzonitrile (2d)}

The title compound was prepared following the general procedure for synthesis of nitriles from carboxylic acids. It was isolated as a yellow solid (36 mg, 24\%).

${ }^{1} \mathrm{H}$ NMR $\left(400 \mathrm{MHz}, \mathrm{CDCl}_{3}\right): \delta=8.35(\mathrm{~d}, J=8.8 \mathrm{~Hz}, 2 \mathrm{H}), 7.88(\mathrm{~d}, J=$ $8.8 \mathrm{~Hz}, 2 \mathrm{H})$

The analytical data were found to be consistent with the literature. ${ }^{35}$

\section{Thiophene-3-carbonitrile (2e)}

The title compound was prepared following the general procedure for synthesis of nitriles from carboxylic acids. It was isolated as pale-yellow oil (22 mg, 20\%).

${ }^{1} \mathrm{H}$ NMR (300 MHz, $\mathrm{CDCl}_{3}$ ): $\delta$ = 7.95 (s, $1 \mathrm{H}$ ), 7.43 (s, $\left.1 \mathrm{H}\right), 7.30$ (s, $1 \mathrm{H}$ ). The analytical data were found to be consistent with the literature. ${ }^{36}$

\section{2-Phenylacetonitrile (2f)}

The title compound was prepared following the general procedure for synthesis of nitriles from carboxylic acids. It was isolated as colorless oil (22 mg, 18\%).

${ }^{1} \mathrm{H} \operatorname{NMR}\left(300 \mathrm{MHz}, \mathrm{CDCl}_{3}\right): \delta=7.41-7.30(\mathrm{~m}, 5 \mathrm{H}), 3.76(\mathrm{~s}, 2 \mathrm{H})$.

The analytical data were found to be consistent with the literature. ${ }^{37}$

\section{4-Acetylbenzonitrile (2g)}

The title compound was prepared following the general procedure for synthesis of nitriles from carboxylic acids. It was isolated as an off white solid (41 mg, 28\%).

${ }^{1} \mathrm{H}$ NMR $\left(300 \mathrm{MHz}, \mathrm{CDCl}_{3}\right): \delta=8.02(\mathrm{~d}, J=8.1 \mathrm{~Hz}, 2 \mathrm{H}), 7.74(\mathrm{~d}, J=$ $8.1 \mathrm{~Hz}, 2 \mathrm{H}), 2.62(\mathrm{~s}, 3 \mathrm{H})$.

The analytical data were found to be consistent with the literature. ${ }^{38}$

\section{tert-Butyl (4-Cyanophenyl)carbamate (2h)}

The title compound was prepared following the general procedure for synthesis of nitriles from carboxylic acids. It was isolated as a yellow solid (48 mg, 22\%).

${ }^{1} \mathrm{H}$ NMR $\left(300 \mathrm{MHz}, \mathrm{CDCl}_{3}\right): \delta=7.80(\mathrm{br} \mathrm{s}, 1 \mathrm{H}), 7.57(\mathrm{~d}, J=8.4 \mathrm{~Hz}, 2 \mathrm{H})$, 7.47 (d, J = 8.4 Hz, 2 H), 6.75 (br s, $1 \mathrm{H}), 1.52(\mathrm{~s}, 9 \mathrm{H})$.

The analytical data were found to be consistent with the literature. ${ }^{39}$

\section{4-Fluorobenzonitrile (2i)}

The title compound was prepared following the general procedure for synthesis of nitriles from carboxamides. It was isolated as a white solid (22 mg, 18\%).

${ }^{1} \mathrm{H}$ NMR $\left(300 \mathrm{MHz}, \mathrm{CDCl}_{3}\right): \delta=7.65-7.70(\mathrm{~m}, 2 \mathrm{H}), 7.15-7.26(\mathrm{~m}, 2 \mathrm{H})$. The analytical data were found to be consistent with the literature. ${ }^{40}$

\section{1-Chloroacetyl-2-pyrrolidinecarbonitrile (3)}

The title compound was prepared following the general procedure for synthesis of nitriles from carboxylic acids. It was isolated as off white solid (52 mg, 30\%).

${ }^{1} \mathrm{H}$ NMR (300 $\mathrm{MHz}, \mathrm{CDCl}_{3}$ ): $\delta$ (4:1 mixture of trans/cis amide rotomers $)=4.88-4.76(\mathrm{~m}, 1 \mathrm{H}), 4.24-4.01(\mathrm{~m}, 2 \mathrm{H}), 3.72-3.46(\mathrm{~m}$, $2 \mathrm{H}), 2.41-2.02(\mathrm{~m}, 4 \mathrm{H})$.

The analytical data were found to be consistent with the literature. ${ }^{7}$

\section{General Procedure for Optimization Studies (Table 3)}

To a solution of benzamide $(1 \mathrm{mmol})$ in $\mathrm{CH}_{2} \mathrm{Cl}_{2}(10 \mathrm{~mL})$ at $-10{ }^{\circ} \mathrm{C}$ was added $\mathrm{Tf}_{2} \mathrm{O}(1.1 \mathrm{mmol})$, followed $\mathrm{Et}_{3} \mathrm{~N}(0.31 \mathrm{~mL}, 2.2 \mathrm{mmol})$, if stated. Progress of the reaction was monitored by TLC. After $4 \mathrm{~h}$, the reaction mixture was diluted with $\mathrm{CH}_{2} \mathrm{Cl}_{2}(20 \mathrm{~mL})$ and washed with aq $\mathrm{NaHCO}_{3}$ $(10 \mathrm{~mL})$ and then brine $(10 \mathrm{~mL})$. The organic layer was dried over anhydrous sodium sulfate, filtered and concentrated under reduced pressure to give the desired product. Pure product was obtained by flash column chromatography, eluting with EtOAc-hexane.

\section{General Procedure for Synthesis of Nitriles 2 from Carboxamide} (Scheme 3)

To a solution of carboxamide $(1 \mathrm{mmol})$ in $\mathrm{CH}_{2} \mathrm{Cl}_{2}(10 \mathrm{~mL})$ at $-10{ }^{\circ} \mathrm{C}$ was added $\mathrm{Tf}_{2} \mathrm{O}(0.19 \mathrm{~mL}, 1.1 \mathrm{mmol})$, followed by addition of $\mathrm{Et}_{3} \mathrm{~N}$ $(0.31 \mathrm{~mL}, 2.2 \mathrm{mmol})$, if stated. Progress of the reaction was monitored by TLC. After $4 \mathrm{~h}$, the reaction mixture was diluted with $\mathrm{CH}_{2} \mathrm{Cl}_{2}(20$ $\mathrm{mL})$ and washed with aq $\mathrm{NaHCO}_{3}(10 \mathrm{~mL})$ and then brine $(10 \mathrm{~mL})$. The organic layer was dried over anhydrous sodium sulfate, filtered and concentrated under reduced pressure to give the desired product. Pure product was obtained by flash column chromatography, eluting with EtOAc-hexane.

\section{Procedure for Scale-up Synthesis of $\mathbf{2 b}$ from Carboxamide (1b)}

To a solution of amide $\mathbf{1 a}(700 \mathrm{mg}, 4.63 \mathrm{mmol})$ in $\mathrm{CH}_{2} \mathrm{Cl}_{2}(20 \mathrm{~mL})$ at $-10{ }^{\circ} \mathrm{C}$ was added $\mathrm{Tf}_{2} \mathrm{O}(0.86 \mathrm{~mL}, 5.09 \mathrm{mmol})$. Progress of the reaction was monitored by TLC. After $4 \mathrm{~h}$, the reaction mixture was diluted with $\mathrm{CH}_{2} \mathrm{Cl}_{2}(90 \mathrm{~mL})$ and washed with aq $\mathrm{NaHCO}_{3}(20 \mathrm{~mL})$ and then brine $(20 \mathrm{~mL})$. The organic layer was dried over anhydrous sodium sulfate, filtered and concentrated under reduced pressure to give pure desired product ( $480 \mathrm{mg}, 78 \%$ ).

Note: By using this procedure, compounds $\mathbf{2 a - i}$ were obtained in excellent yields (Scheme 3 ) and their spectroscopic data found to be in accordance with previously synthesized compounds as mentioned in Scheme 2.

\section{4-Cyano- $N, N$-dimethylbenzamide ( $2 \mathrm{j}$ )}

The title compound was prepared following the general procedure for synthesis of nitriles from carboxamides. It was isolated as an off white solid (143 mg, 82\%).

${ }^{1} \mathrm{H}$ NMR $\left(300 \mathrm{MHz}, \mathrm{CDCl}_{3}\right): \delta=7.71(\mathrm{~d}, J=7.2 \mathrm{~Hz}, 2 \mathrm{H}), 7.52(\mathrm{~d}, J=$ $7.5 \mathrm{~Hz}, 2 \mathrm{H}), 3.13$ (s, $3 \mathrm{H}), 2.96$ (s, $3 \mathrm{H}$ ).

The analytical data were found to be consistent with the literature. ${ }^{41}$ 


\section{(3-Indolyl)butanenitrile (2k)}

The title compound was prepared following the general procedure for synthesis of nitriles from carboxamides. It was isolated as a brown solid (136 mg, 74\%).

${ }^{1} \mathrm{H}$ NMR $\left(300 \mathrm{MHz}, \mathrm{CDCl}_{3}\right): \delta=8.09(\mathrm{br} \mathrm{s}, 1 \mathrm{H}), 7.58(\mathrm{~d}, J=8 \mathrm{~Hz}, 1 \mathrm{H})$, 7.37 (d, $J=8.0 \mathrm{~Hz}, 1 \mathrm{H}), 7.23-7.04(\mathrm{~m}, 3 \mathrm{H}), 7.04$ (br s, $1 \mathrm{H}), 2.95$ (t, $J=$ $7.2 \mathrm{~Hz}, 2 \mathrm{H}), 2.34(\mathrm{t}, J=6.9 \mathrm{~Hz}, 2 \mathrm{H}), 2.06(\mathrm{~m}, 2 \mathrm{H})$.

The analytical data were found to be consistent with the literature. ${ }^{42}$

\section{3-(Dimethylamino)benzonitrile (21)}

The title compound was prepared following the general procedure for synthesis of nitriles from carboxamides. It was isolated as a brown solid (117 mg, 80\%).

${ }^{1} \mathrm{H}$ NMR $\left(300 \mathrm{MHz}, \mathrm{CDCl}_{3}\right): \delta=7.19($ br s, $2 \mathrm{H}), 6.90-6.83(\mathrm{~m}, 3 \mathrm{H})$, $2.91(\mathrm{~s}, 6 \mathrm{H})$

The analytical data were found to be consistent with the literature. ${ }^{43}$

\section{Terephthalonitrile (2m)}

The title compound was prepared following the general procedure for synthesis of nitriles from carboxamides. It was isolated as a white solid (97 mg, 76\%).

${ }^{1} \mathrm{H}$ NMR $\left(300 \mathrm{MHz}, \mathrm{CDCl}_{3}\right): \delta=7.8(\mathrm{~s}, 4 \mathrm{H})$.

The analytical data were found to be consistent with the literature. ${ }^{44}$

\section{4-Cyanoacetanilide (2n)}

The title compound was prepared following the general procedure for synthesis of nitriles from carboxamides. It was isolated as a white solid (129 mg, 80\%).

${ }^{1} \mathrm{H}$ NMR $\left(400 \mathrm{MHz}\right.$, DMSO- $\left.d_{6}\right): \delta=10.37$ (br s, $1 \mathrm{H}$ ), $7.75(\mathrm{~s}, 4 \mathrm{H}), 2.08$ (s, $3 \mathrm{H})$.

The analytical data were found to be consistent with the literature. ${ }^{38}$

\section{(E)-3-Phenylprop-2-enenitrile (2o)}

The title compound was prepared following the general procedure for synthesis of nitriles from carboxamides. It was isolated as an off white solid (86 mg, 67\%).

${ }^{1} \mathrm{H}$ NMR $\left(400 \mathrm{MHz}, \mathrm{CDCl}_{3}\right): \delta=7.43-7.37(\mathrm{~m}, 6 \mathrm{H}), 5.87(\mathrm{~d}, J=13.5 \mathrm{~Hz}$, $1 \mathrm{H})$.

The analytical data were found to be consistent with the literature. ${ }^{40}$

\section{4-Formylbenzonitrile (2p)}

The title compound was prepared following the general procedure for synthesis of nitriles from carboxamides. It was isolated as a yellow solid (105 mg, 80\%).

$\left.{ }^{1} \mathrm{H} \mathrm{NMR} \mathrm{(300} \mathrm{MHz,} \mathrm{CDCl}_{3}\right): \delta=10.10(\mathrm{~s}, 1 \mathrm{H}), 8.01(\mathrm{~d}, J=7.8 \mathrm{~Hz}, 2 \mathrm{H})$, $7.85(\mathrm{~d}, J=7.8 \mathrm{~Hz}, 2 \mathrm{H})$.

The analytical data were found to be consistent with the literature. ${ }^{35}$

\section{4-Methylbenzonitrile (2q)}

The title compound was prepared following the general procedure for synthesis of nitriles from carboxamides. It was isolated as a white solid (99 mg, 83\%).

${ }^{1} \mathrm{H}$ NMR $\left(300 \mathrm{MHz}, \mathrm{CDCl}_{3}\right): \delta=7.57(\mathrm{~d}, J=7.8 \mathrm{~Hz}, 2 \mathrm{H}), 7.28(\mathrm{~d}, J=$ $7.5 \mathrm{~Hz}, 2 \mathrm{H}), 2.44$ (s, $3 \mathrm{H})$.

The analytical data were found to be consistent with the literature. ${ }^{38}$

\section{4-Aminobenzonitrile (2r)}

The title compound was prepared following the general procedure for synthesis of nitriles from carboxamides. It was isolated as an off white solid (97 mg, 82\%).

${ }^{1} \mathrm{H}$ NMR $\left(300 \mathrm{MHz}, \mathrm{CDCl}_{3}\right): \delta=7.40(\mathrm{~d}, J=7.8 \mathrm{~Hz}, 2 \mathrm{H}), 6.64(\mathrm{~d}, J=$ $8.1 \mathrm{~Hz}, 2 \mathrm{H}), 4.20$ (br s, $2 \mathrm{H}$ ).

The analytical data were found to be consistent with the literature. ${ }^{38}$

\section{4-(Bromomethyl)benzonitrile (2s)}

The title compound was prepared following the general procedure for synthesis of nitriles from carboxamides. It was isolated as a white solid (172 mg, 88\%).

${ }^{1} \mathrm{H}$ NMR $\left(300 \mathrm{MHz}, \mathrm{CDCl}_{3}\right): \delta=7.64(\mathrm{~d}, J=6.6 \mathrm{~Hz}, 2 \mathrm{H}), 7.50(\mathrm{~d}, J=$ $8.1 \mathrm{~Hz}, 2 \mathrm{H}), 4.48$ (s, $2 \mathrm{H}$ ).

The analytical data were found to be consistent with the literature. ${ }^{45}$

\section{4-Hydroxybenzonitrile (2t)}

The title compound was prepared following the general procedure for synthesis of nitriles from carboxamides. It was isolated as a white solid (62 mg, 52\%).

${ }^{1} \mathrm{H}$ NMR $\left(300 \mathrm{MHz}\right.$, DMSO- $\left.\mathrm{d}_{6}\right): \delta=10.62(\mathrm{~s}, 1 \mathrm{H}), 7.63(\mathrm{~d}, J=8.1 \mathrm{~Hz}$, $2 \mathrm{H}), 6.89$ (d, $J=7.8 \mathrm{~Hz}, 2 \mathrm{H})$.

The analytical data were found to be consistent with the literature. ${ }^{35}$

\section{4-(Hydroxymethyl)benzonitrile (2u)}

The title compound was prepared following the general procedure for synthesis of nitriles from carboxamides. It was isolated as an off white solid (95 mg, 84\%).

${ }^{1} \mathrm{H}$ NMR $\left(300 \mathrm{MHz}, \mathrm{CDCl}_{3}\right): \delta=7.67(\mathrm{~d}, J=7.8 \mathrm{~Hz}, 2 \mathrm{H}), 7.51(\mathrm{~d}, J=$ $8.1 \mathrm{~Hz}, 2 \mathrm{H}), 4.61(\mathrm{~s}, 2 \mathrm{H})$.

The analytical data were found to be consistent with the literature. ${ }^{46}$

\section{1,3-Benzodioxole-5-carbonitrile (2v)}

The title compound was prepared following the general procedure for synthesis of nitriles from carboxamides. It was isolated as a white solid (106 mg, 72\%).

${ }^{1} \mathrm{H}$ NMR $\left(300 \mathrm{MHz}, \mathrm{CDCl}_{3}\right): \delta=7.22(\mathrm{dd}, J=8.1,1.7 \mathrm{~Hz}, 1 \mathrm{H}), 7.04(\mathrm{~d}$, $J=1.5 \mathrm{~Hz}, 1 \mathrm{H}), 6.87(\mathrm{~d}, J=8.1 \mathrm{~Hz}, 1 \mathrm{H}), 6.07(\mathrm{~s}, 2 \mathrm{H})$.

The analytical data were found to be consistent with the literature. ${ }^{47}$

\section{Benzyl (1-Cyano-2-phenylethyl)carbamate (2w)}

The title compound was prepared following the general procedure for synthesis of nitriles from carboxamides. It was isolated as a white solid (215 mg, 76\%).

${ }^{1} \mathrm{H}$ NMR $\left(300 \mathrm{MHz}, \mathrm{CDCl}_{3}\right): \delta=7.26-7.41(\mathrm{~m}, 10 \mathrm{H}), 5.38(\mathrm{~d}, J=7.2 \mathrm{~Hz}$, $1 \mathrm{H}), 5.10$ (s, $2 \mathrm{H}), 4.86(\mathrm{~m}, 1 \mathrm{H}), 3.13(\mathrm{~d}, J=5.7 \mathrm{~Hz}, 2 \mathrm{H})$.

The analytical data were found to be consistent with the literature. ${ }^{48}$

\section{tert-Butyl (1-Cyano-2-phenylethyl)carbamate (2x)}

The title compound was prepared following the general procedure for synthesis of nitriles from carboxamides. It was isolated as a white solid (192 mg, 78\%).

${ }^{1} \mathrm{H}$ NMR $\left(300 \mathrm{MHz}, \mathrm{CDCl}_{3}\right): \delta=7.26-7.36(\mathrm{~m}, 5 \mathrm{H}), 4.94(\mathrm{~d}, J=8.1 \mathrm{~Hz}$, $1 \mathrm{H}), 4.83(\mathrm{~m}, 1 \mathrm{H}), 3.13(\mathrm{~m}, 2 \mathrm{H}), 1.43(\mathrm{~s}, 9 \mathrm{H})$.

The analytical data were found to be consistent with the literature. ${ }^{49}$ 
(9H-Fluoren-9-yl)methyl(1-cyano-3-methylbutyl)carbamate (2y) The title compound was prepared following the general procedure for synthesis of nitriles from carboxamides. It was isolated as a white solid (242 $\mathrm{mg}, 72 \%)$.

${ }^{1} \mathrm{H} \mathrm{NMR}\left(300 \mathrm{MHz}, \mathrm{CDCl}_{3}\right): \delta=7.25-7.78(\mathrm{~m}, 8 \mathrm{H}), 5.07(\mathrm{br}, 1 \mathrm{H}), 4.51-$ $4.63(\mathrm{~m}, 3 \mathrm{H}), 4.21(\mathrm{~m}, 1 \mathrm{H}), 1.65-1.81(\mathrm{~m}, 3 \mathrm{H}), 0.97(\mathrm{~d}, J=5.4 \mathrm{~Hz}$, $6 \mathrm{H})$.

The analytical data were found to be consistent with the literature..$^{50}$

\section{tert-Butyl (1-Cyano-2-(1H-indol-3-yl)ethyl)carbamate (2z)}

The title compound was prepared following the general procedure for synthesis of nitriles from carboxamides. It was isolated as a white solid (204 mg, 71\%).

${ }^{1} \mathrm{H}$ NMR $\left(300 \mathrm{MHz}\right.$, acetone- $\left.d_{6}\right): \delta=10.31($ br s, $1 \mathrm{H}), 7.68(\mathrm{~d}, J=$ $7.8 \mathrm{~Hz}, 1 \mathrm{H}), 7.43(\mathrm{~d}, J=7.9 \mathrm{~Hz}, 1 \mathrm{H}), 7.34(\mathrm{~s}, 1 \mathrm{H}), 7.15-7.02(\mathrm{~m}, 2 \mathrm{H})$, 6.92 (br m, $1 \mathrm{H}$ ), 4.87 (q, J = 8.1 Hz, $1 \mathrm{H}), 3.34(\mathrm{~m}, 2 \mathrm{H}), 1.39$ (s, $9 \mathrm{H})$.

The analytical data were found to be consistent with the literature. ${ }^{51}$

\section{Funding Information}

We would like to thank the Translational Health Science and Technology Institute (THSTI) for intramural research funding and DBT-BIRAC for grant BT/CRS0200/CRS-10/16.

\section{Acknowledgment}

We would like to thank Dr Yashwant (Scientist C, THSTI) for his support in performing HRMS experiments.

\section{Supporting Information}

Supporting information for this article is available online at https://doi.org/10.1055/s-0037-1610154.

\section{References}

(1) Fleming, F. F.; Yao, L.; Ravikumar, P. C.; Funk, L.; Shook, B. C. J. Med. Chem. 2010, 53, 7902.

(2) (a) Fleming, F. F. Nat. Prod. Rep. 1999, 16, 597. (b) Monadjemi, S.; El Roz, M.; Richard, C.; Ter Halle, A. Environ. Sci. Technol. 2011, 45, 9582. (c) Scheuermann, H.; Seefelder, M. US Pat. 3,652,636, 1972.

(3) (a) Murphy, T.; Case, H. L.; Ellsworth, E.; Hagen, S.; Huband, M.; Joannides, T.; Limberakis, C.; Marotti, K. R.; Ottolini, A. M.; Rauckhorst, M.; Starr, J.; Stier, M.; Taylor, C.; Zhu, T.; Blaser, A.; Denny, W. A.; Lu, G.-L.; Smaill, J. B.; Rivault, F. Bioorg. Med. Chem. Lett. 2007, 17, 2150. (b) Markus, B.; Kwon, C. J. Pharm. Sci. 1994, 83, 1729. (c) Patterson, A. W.; Wood, W. J. L.; Hornsby, M.; Lesley, S.; Spraggon, G.; Ellman, J. A. J. Med. Chem. 2006, 49, 6298.

(4) (a) Rappoport, Z. Chemistry of the Cyano Group; Wiley: Weinheim, 1970. (b) Larock, R. C. Comprehensive Organic Transformations: A Guide to Functional Group Preparations; Wiley: Weinheim, 1989.
(5) (a) Movassaghi, M.; Hill, M. D. Nat. Protoc. 2007, 2, 2018. (b) Yang, J.; Karver, M. R.; Li, W.; Sahu, S.; Devaraj, N. K. Angew. Chem. Int. Ed. 2012, 51, 5222. (c) Madkour, H. M. F.; Elgazwy, A. S. H. Curr. Org. Chem. 2007, 11, 853. (d) Elgazwy, A. S. S. H.; Refaee, M. R. M. Org. Chem.: Curr. Res. 2013, 117, 1.

(6) (a) Zanon, J.; Klapars, A.; Buchwald, S. L. J. Am. Chem. Soc. 2003, 125, 2890. (b) Yin, W.; Wang, C.; Huang, H. Org. Lett. 2013, 15, 1850. (c) Wu, Q.; Luo, Y.; Lei, A.; You, J. J. Am. Chem. Soc. 2016, 138, 2885. (d) Noh, J. H.; Kim, J. J. Org. Chem. 2015, 80, 11624. (e) Rokade, B. V.; Prabhu, J. R. J. Org. Chem. 2012, 77, 5364.

(7) (a) Villhauer, E. B.; Brinkman, J. A.; Naderi, G. B.; Burkey, B. F.; Dunning, B. E.; Prasad, K.; Mangold, B. L.; Russell, M. E.; Hughes, T. E. J. Med. Chem. 2003, 46, 2774. (b) Singh, S. K.; Manne, N.; Pal, M. Beilstein J. Org. Chem. 2008, 4, 20.

(8) Miller, C. S. Org. Synth. 1955, 3, 646.

(9) Cope, A. C.; Cotter, R. J.; Estes, L. L. Org. Synth. 1963, 4, 62.

(10) Imamoto, T.; Takaoka, T.; Yokoyama, M. Synthesis 1983, 142.

(11) Huber, V. J.; Bartsch, R. A. Tetrahedron 1998, 54, 9281.

(12) Kangani, C. O.; Day, B. W.; Kelley, D. E. Tetrahedron Lett. 2007, 48, 5933.

(13) Telvekar, V. N.; Rane, R. A. Tetrahedron Lett. 2007, 48, 6051.

(14) Miyagi, K.; Moriyama, K.; Togo, H. Eur. J. Org. Chem. 2013, 5886.

(15) (a) Huang, P. Q.; Huang, Y. H.; Geng, H.; Ye, J. L. Sci. Rep. 2016, 6, 28801. (b) Huang, P. Q.; Huang, Y. H.; Xiao, K. J. J. Org. Chem. 2016, 81, 9020. (c) Huang, P. Q.; Huang, Y. H.; Xiao, K. J.; Wang, Y.; Xia, X. E. J. Org. Chem. 2015, 80, 2861. (d) Cyr, P.; Regnier, S.; Bechara, W. S.; Charette, A. B. Org. Lett. 2015, 17, 3386. (e) Pelletier, G.; Bechara, W. S.; Charette, A. B. J. Am. Chem. Soc. 2010, 132, 12817. (f) Barbe, G.; Charette, A. B. J. Am. Chem. Soc. 2008, 130, 18. (g) Charette, A. B.; Grenon, M. J. Org. Chem. 2003, 68,5792 .

(16) Noguchi, T.; Sekine, M.; Yokoo, Y.; Jung, S.; Imai, N. Chem. Lett. 2013, 42, 580.

(17) Bose, D. S.; Jayalakshmi, B. Synthesis 1999, 64.

(18) Ma, X.; He, Y.; Lu, M. Synth. Commun. 2014, 44, 474.

(19) Yin, H.; de Almeida, A. M.; de Almeida, M. V.; Lindhardt, A. T.; Skrydstrup, T. Org. Lett. 2015, 17, 1248.

(20) Ren, W.; Yamane, M. J. Org. Chem. 2010, 75, 8410.

(21) Schonbrunn, E.; Lawrence, N. J.; Lawrence, H. R. PCT Int. Appl. 2017066428, 20 Apr, 2017.

(22) Owston, N. A.; Parker, A. J.; Williams, J. M. J. Org. Lett. 2007, 9 , 73.

(23) Mewshaw, R. E.; Zhou, D.; Zhou, P.; Shi, X.; Hornby, G.; Spangler, T.; Scerni, R.; Smith, D.; Schechter, L. E.; Andree, T. H. J. Med. Chem. 2004, 47, 3823.

(24) Rombouts, F.; Franken, D.; Martinez-Lamenca, C.; Braeken, M.; Zavattaro, C.; Chen, J.; Trabanco, A. A. Tetrahedron Lett. 2010, 51 , 4815.

(25) Li, Y. T.; Liao, B. S.; Chen, H. P.; Liu, S. T. Synthesis 2011, 2639.

(26) Gnanamgari, D.; Crabtree, R. H. Organometallics 2009, 28, 922.

(27) Bonne, D.; Dekhane, M.; Zhu, J. J. Am. Chem. Soc. 2005, 127, 6926.

(28) Huang, Y.; Chen, T.; Li, Q.; Zhou, Y.; Yin, S. F. Org. Biomol. Chem. 2015, 13, 7289 .

(29) Jevtic, I. I.; Dosen-Micovic, L.; Ivanovic, E. R.; Ivanovic, M. D. Synthesis 2016, 48, 1550.

(30) Chen, S. T.; Jang, M. K.; Wang, K.-T. Synthesis 1993, 858.

(31) Doroski, M. D.; Maderna, A.; O'Donnell, C. J.; Subramanyam, C.; Vetelino, B. C.; Dushin, R. G.; Strop, P.; Graziani, E. I. PCT Int. Appl. 2013072813, 23 May, 2013.

(32) Bailen, M. A.; Chinchilla, R.; Dodsworth, D. J.; Najera, C. Tetrahedron Lett. 2000, 41, 9809. 
191

THIEME

SynOpen

A. Rana et al.

(33) Zemolka, S.; Nolte, B.; Linz, K.; Saunders, D. J.; Schroeder, W.; Englberger, W.; Theil, F.; Schick, H.; Kaufmann, J.; Gebauer, J. PCT Int. Appl. 2009118174, 01 Oct, 2009.

(34) Xia, Z.; Smith, C. D. J. Org. Chem. 2001, 66, 3459.

(35) Ghosh, P.; Pariyar, G. C.; Saha, B.; Subba, R. Synth. Commun. 2016, 46, 685.

(36) Ushkov, A. V.; Grushin, V. V. J. Am. Chem. Soc. 2011, 133, 10999.

(37) Nambo, M.; Yar, M.; Smith, J. D.; Crudden, C. M. Org. Lett. 2015, 17,50 .

(38) Zhang, G. Y.; Yu, J. T.; Hu, M. L.; Cheng, J. J. Org. Chem. 2013, 78, 2710.

(39) Roosen, P. C.; Kallepalli, V. A.; Chattopadhyay, B.; Singleton, D. A.; Maleczka, R. E. Jr; Smith, I. M. R. II J. Am. Chem. Soc. 2012, 134, 11350.

(40) Yu, L.; Zhang, H.; Li, X.; Ye, J.; Liu, J.; Xu, Q.; Lautens, M. Org. Lett. 2014, 16, 1346.

(41) Das, S.; Addis, D.; Zhou, S.; Junge, K.; Beller, M. J. Am. Chem. Soc. 2010, 132, 1770.
(42) Pedras, M. S. C.; Minic, Z.; Thongbam, P. D.; Bhaskar, V.; Montaut, S. Phytochemistry 2010, 71, 1952.

(43) Augustine, J. K.; Atta, R. N.; Ramappa, B. K.; Boodappa, C. Synlett 2009, 3378.

(44) Cai, L.; Liu, X.; Tao, X.; Shen, D. Synth. Commun. 2004, 34, 1215.

(45) Cantillo, D.; de Frutos, O.; Rincon, J. A.; Mateos, C.; Kappe, C. O. J. Org. Chem. 2014, 79, 223.

(46) Cohen, D. T.; Buchwald, S. L. Org. Lett. 2015, 17, 202.

(47) Shimojo, H.; Moriyama, K.; Togo, H. Synthesis 2013, 45, 2155.

(48) Hoang, C. T.; Bouillere, F.; Johannesen, S.; Zulauf, A.; Panel, C.; Pouilhes, A.; Gori, D.; Alezra, V.; Kouklovsky, C. J. Org. Chem. 2009, 74, 4177.

(49) Sureshbabu, V. V.; Naik, S. A.; Nagendra, G. Synth. Commun. 2009, 39, 395.

(50) Madhu, C.; Panguluri, N. R.; Narendra, N.; Panduranga, V.; Sureshbabu, V. V. Tetrahedron Lett. 2014, 55, 6831.

(51) Tao, H.; Weng, Y.; Zhuo, R.; Chang, G.; Urbatsch, I. L.; Zhang, Q. ChemBiochem 2011, 12, 868.

Georg Thieme Verlag Stuttgart · New York - SynOpen 2018, 2, 180-191 